\title{
Analisis Kepuasan Masyarakat dalam Pelayanan Kepala Desa Medan Estate Kecamatan Percut Sei Tuan
}

\section{Analysis of Community Satisfaction Village Head's Service of Medan Estate on The District of Percut Sei Tuan}

\author{
Andreas Roberto. S*, Abdul Kadir \& Nina Angelia \\ Program Srudi Administrasi Publik, Fakultas Ilmu Sosial dan Ilmu Politik, \\ Universitas Medan Area, Indonesia
}

\begin{abstract}
Abstrak
Penelitian ini bertujuan untuk mengetahui Analisis Kepuasan Masyarakat terhadap Kinerja Kepala Desa Medan Estate, dalam Kepuasan Masyarakat pada kinerja kepala desa. Permasalahan yang dapat diketahui dalam penelitian ini adalah: 1) Bagaimana proses dalam pelayanan masyarakat terhadap Kinerja Kepala Desa medan Estate Kecamatan Percut Sei Tuan Kabupaten Deli Serdang. 2) Bagaimana faktor - faktor pendukung dan penghambat dalam pelayanan masyarakat di kantor kepala Desa Medan Estate. Penelitian ini menggunakan metode Kualitatif untuk menganalisis data dengan cara mendeskripsikan data yang telah terkumpul. Mengambil lokasi penelitian di Kantor Kepala Desa Medan Estate Kecamatan Percut Sei Tuan Kabupaten Deli Serdang. Sumber data dalam penelitian ini adalah masyarakat dan kepala desa. Data dikumpulkan berdasarkan wawancara dan dokumentasi yang dilakukan peneliti. Hasil penelitian ini menunjukkan bahwa Analisis kepuasan masyarakat dalam Kinerja Kepala Desa Medan Estate, ditinjau dari berbagai wawancara pada Masyarakat Desa Medan Estate dan para perangkat desa untuk meningkatkan kepuasan masyarakat terhadap kinerja Kepala Desa Medan Estate.
\end{abstract}

Kata Kunci: Analisis Kepuasan Masyarakat, Kinerja Pelayanan

\begin{abstract}
The purpose of this study is to Analysis of Community Satisfaction with the Performance of Head Village in the Medan Estate. The Problems can be identified in this study are: 1) How the process of service in community to Performance's Head of the Field in Percut Sei Tuan District Deli Serdang Regency. 2) What are the supporting and inhibiting factors in community service in the head office of Desa Medan Estate. Data Analysis used in this study is the Qualitative method for analyzing the data by describing the collected data who took the research location at the Office of the Head of the Medan Estate Village PercutSei Tuan Deli Serdang District. The data sources in this study were the community and the Head village. Data is collected based on interviews and documentation. The results of this study indicate that the analysis of community satisfaction in the Performance of the Village Head of Medan Estate, was reviewed from various interviews with the Medan Estate Village Community and village officials to increase community satisfaction with the performance of the Medan Estate Village Chief.
\end{abstract}

Keywords: Community Satisfaction Analysis, Service Performance

How to Cite: Roberto, S.A. Kadir, A. \& Angelia, N. (2019). Analisis Kepuasan Masyarakat Dalam Pelayanan Kepala Desa Medan Estate Kecamatan Percut Sei Tuan. Jurnal Ilmu Pemerintahan, Administrasi Publik, Ilmu Komunikasi (JIPIKOM), 1(1) 2019: 35-41,

*E-mail: andreas roberto. $s$ @gmail.com

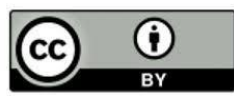




\section{PENDAHULUAN}

Dalam Undang-undang Nomor 32 Tahun 2004 tentang Pemerintahan Daerah, Desa Sebagai kesatuan masyarakat hukum yang memiliki batas wilayah, yang berwenang untuk mengatur dan mengurus kepentingan masyarakat setempat berdasarakan asalusul dan adat-istiadat setempat yang diakui dan dihormati dalam sistem pemerintahan Negara Kesatuan Republik Indonesia. Seiring dengan perkembangan masyarakat tersebut, kebutuhan akan pelayanan yang semakin kompleks serta pelayanan yang semakin baik, cepat, dan tepat sangat diperlukan oleh masyarakat.

Aparatur yang berada ditengah-tengah masyarakat tersebut harus mampu memberikan pelayanan yang sesuai dengan kebutuhan masyarakat. Dalam menjalankan tugasnya, aparatur merupakan subsistem dari penyelenggaraan pemerintahan yang memiliki kewenangan untuk mengatur dan mengurus rumah tangganya sendiri secara berdaya dan berhasil guna sesuai dengan perkembangan pemerintahan. Kegiatan penyelenggaraan pemerintah desa di Desa Medan Estate dilaksanakan oleh aparatur desa dengan jumlah 13 (tiga belas) orang yang terdiri atas Kepala Desa dan Perangkat Desa. Penyelenggaraan pemerintah desa akan tersusun dan semakin terarah lebih baik bahkan lebih maju apabila kinerja segenap aparatur desa dalam memberikan pelayanan tidak lambat, tidak berbelit-belit dan tidak formalitas, sehingga masyarakat merasa kepentingannya dapat terlayani dengan baik.

Pada pengamatan penulis ketika mengadakan observasi lapangan di kantor kepala desa di Desa Tegalmlati pada tanggal 16 - 20 februari tahun 2015, realitanya dalam lapangan adalah kualitas sumber daya aparatur desa masih rendah, dibuktikan dengan tingkat pendidikan aparatur pada umumnya hanya lulus Sekolah Dasar (SD) sebanyak 2 orang, SMP sebanyak 4 orang dan SMA sebanyak 4 orang serta 3 orang lainnya sarjana, lalu mengenai jam mulai kerja telah ditentukan yaitu pukul 08:00 WIB dan selesai pada pukul 14:00 WIB tetapi kenyataannya sebagian besar dari jumlah perangkat desa yang ada selalu berangkat siang yaitu jam 09:00 WIB dan ada pula yang berangkat lebih dari jam 09:00 WIB, kemudian ketika waktu menunjukkan jam pulang kerja, semua perangkat desa pulang lebih awal dari jam pulang kerja yang telah ditentukan, dengan alasan bahwa tidak ada lagi masyarakat yang berurusan di kantor. Banyak masyarakat mengeluh dengan pelayanan yang diberikan karena dalam proses pembuatan KTP sangat berbelit-belit dan menunggu waktu yang lama dengan alasan masih dalam proses pembuatan. Hal ini yang perlu disoroti adalah kinerja dari Kepala Desa selaku pemimpin desa yang mempunyai tugas mengatur dan mengelola desa sesuia dengan aturan-aturan yang ada agar tujuan yang diharapkan pemerintah desa dapat tercapai.

Pelayanan sering dijadikan tolak ukur keberhasilan suatu organisasi atau instansi pemerintah terutama ditingkat desa untuk memenuhi keinginan masyarakat sehingga pemerintah dituntut untuk terus meningkatkan pelayanan kepada masyarakat. Masyarakat setiap waktu selalu menuntut pelayanan publik yang berkualitas dari pemerintah, meskipun tuntutan tersebut sering tidak sesuai dengan harapan. Hal ini menimbulkan dampak buruk terhadap perkembangan kualitas pelayanan yakni sering terlantarnya upaya peningkatan pelayanan dan kurang berkembangnya inovasi dalam pelayanan serta kurang terpacunya Pemerintah Daerah untuk memperbaiki kualitas 
pelayanan. Dalam rangka mewujudkan pelayanan prima kepada masyarakat, Pemerintah telah mengeluarkan Keputusan Menteri Pendayagunaan Aparatur Negara Nomor 63 Tahun 2003 tentang Pedoman Umum Penyelenggaraan

Pelayanan Publik. Fakta yang terjadi saat ini, masih dijumpai kelemahan yang secara umum merupakan pelayanan aparatur Pemerintah belum berjalan efektif. Kelemahan tersebut antara lain pelayanan rumit dan tidak sederhana, kurang adanya kepastian persyaratan administratif, kurang adanya keterbukaan prosedur dalam memperoleh pelayanan (Cahyadi, B., dan Abdul K., 2015).

Kepuasan merupakan fungsi dari perbedaan antara kinerja yang dirasakan dengan harapan. Apabila kinerja di bawah harapan, maka masyarakat akan kecewa. Bila kinerja sesuai dengan harapan, maka masyarakat akan puas. Menurut (Supranto, 1997:23), Kepuasan adalah tingkat Perasaan seseorang setelah membandingkan kinerja atau hasil yang dirasakan dengan harapannya. Faktor utama penentu kepuasan masyarakat adalah persepsi terhadap kualitas jasa (Lupiyoadi \& Hamdani, 2006; Hendrawan, A.I. Kusmanto, H. \& Warjio., 2018). Terdapat lima faktor yang harus diperhatikan oleh organisasi pelayanan dalam menentukan tingkat kepuasan public dalam (Lupiyoadi \& Hamdani, 2006; Sari, P., \& Bahrum J., 2016.) yaitu; harga, biaya, dan emosional. Menurut (Supratna, 2003; Sukamma, L.E., dan Abdul M., 2014) pelaksanaan Pelayanan Publik oleh aparatur Pemerintah kepada masyarakat berkaitan erat dengan upaya untuk menciptakan kepuasan masyarakat sebagai penerima layanan.

Kinerja adalah melakukan suatu kegiatan dan menyempurnakan sesuai dengan tanggungjawabnya dengan hasil seperti yang diharapkan. Lijan Sinambela (2010) menyatakan bahwa "Kinerja adalah hasil kerja yang dapat dicapai oleh pegawai atau sekelompok pegawai dalam suatu organisasi, sesuai dengan wewenang dan tanggungjawab masing-masing. Dalam hal ini kinerja Kepala Desa Medan Estate yang sangat diharapkan olehmasyarakat dimana kinerja ini akan berpengaruh besar terhadap kepuasan masyarakat dalam artian harapan masyarakat ini dititipkan di kepala desa dari kinerja inilah harapan masyarakat tadi dapat terwujud atau tidaknya. Pelayanan Publik merupakan kewajiban dan tugas yang harus diselenggarakan oleh Pemerintah. Melayani kebutuhan publik yang lebih baik sesuai dengan prinsip-prinsip tata kelola pemerintahan yang baik (good governance) dan demokratis. Menurut Undang-Undang No. 25 Tahun 2009 Tentang Pelayanan Publik diuraikan bahwa Pelayanan Publik adalah: "Segala bentuk kegiatan dalam rangka peraturan, pembinaan, bimbingan, penyediaan fasilitas, jasa dan lainnya yang dilaksanakan oleh aparatur pemerintahan sebagai upaya pemenuhan kebutuhan kepada masyarakat sesuai ketentuan Perundang-Undangan yang berlaku".

Pelayanan Publik didefinisikan sebagai serangkaian aktivitas yang dilakukan oleh birokrasi publik untuk memenuhi kebutuhan warga pengguna (Dwiyanto, 2005:141). Kepmenpan No.63/KEP/M.PAN/7/2003, pelayanan publik adalah segala kegiatan pelayanan yang dilaksanakan oleh penyelenggara pelayanan publik sebagai upaya pemenuhan kebutuhan penerima pelayanan maupun pelaksanaan ketentuan peraturan perundang-undangan. Faktor-faktor yang dapat mempengaruhi kualitas pelayanan 
publik yang antara lain sebagai berikut Pasolong (2007) yaitu; struktur Organisasi, dan Kemampuan Aparat.

Pengertian desa Menurut (Beratha, 2000) "desa atau dengan nama aslinya yang setingkat yang merupakan kesatuan masyarakat hukum berdasarkan susunan asli adalah suatu "badan hukum" dan adalah pula "badan pemerintahan" yang merupakan bagian wilayah kecamatan atau wilayah yang melingkunginya". Berdasarkan sejarah pertumbuhan desa tersebut setidaknya ada empat tipe desa di Indonesia sejak awal pertumbuhannya sampai sekarang, yaitu; Desa adat, Desa Desa administrasi, Desa Otonom sebagai local Self-government, dan desa campuran (adat dan semi otonom) timbal balik dengan daerah-daerah lain". Menurut teori desentralisasi atau otonomi daerah, penyerahan urusan pemerintahan hanya dari pemerintah pusat. Desa dan UU No.32 Tahun 2004 adalah tentang Pemerintahan Daerah, Pemerintah Desa memiliki otonomi Desa dalam penyelenggaraan Pemerintahan Desa.

Kepala Desa mempunyai tugas yang cukup berat dalam penyelenggarakan pemerintah desa berdasarkan Undang-Undang No.32 Tahun 2004 tentang Pemerintahan Daerah, Kepala Desa dipilih langsung oleh dan dari penduduk desa Warga Negara Republik Indonesia yang syarat selanjutnya dan tata cara pemilihannya diatur oleh Perda yang berpedoman pada Peraturan Pemerintah. Menurut ketentuan Undang-Undang Nomor 32 Tahun 2004 Tentang Pemerintahan Daerah, desa dapat disebut dengan istilah atau nama yang lain. Pemerintah Desa dalam menjalankan tugas dan fungsinya menerapkan prinsip koordinasi, integrasi, dan sinkronisasi. Dalam menyelenggarakan tugas dan fungsinya, kepala Desa bertanggung jawab kepada rakyat melalui BPD dan menyampaikan laporan mengenai pelaksanaan tugasnya kepada Bupati tembusan Camat.

Menurut Pasal 209 Undang- Undang Nomor 32 Tahun 2004, urusan pemerintah yang menjadi kewenangan desa adalah: Urusan pemerintahan yang sudah ada berdasarkan hak asal-usul desa; Urusan pemerintahan yang menjadi kewenangan kabupaten atau kota yang diserahkan pengaturannya kepada desa; Tugas pembantuan dari pemerintah, pemerintah provinsi, dan atau pemerintah Kabupaten atau Kota; Urusan pemerintahan lainnya yang oleh peraturan perundang-undangan diserahkan kepada desa.

Kepala Desa mempunyai tugas menyelenggarakan urusan pemerintah pembangunan, dan kemasyarakatan dalam melaksanakan tugasnya Kepala Desa mempunyai wewenang: Kepala desa Memimpin penyelenggaraan pemerintahan desa, pelaksaan pembangunan desa, pembinaan kemasyarakatan desa, dan memperdayaan masyarakat desa, berdasarkan kebijakan yang ditetapkan bersama BPD. Kepala desa bertugas menyelenggarakan pemerintahan desa, yaitu: memimpin penyelenggarakan pemerintrahan desa berdasarkan kebijakan yang di tetapkan bersama BPD; (2) mengajukan rancangan peraturan desa. Menetapkan peraturan desa yang telah mendapat persetujuan bersama BPD. Menyusun dan mengajukan rancangan peraturan desa mengenal APBDesa untuk dibahas dan ditetapkan bersama BPD. Membina kehidupan masyarakat desa. Membina perekonomian desa. Mengkoordinasikan pembangunan desa secara partisipatif. Mewakili desanya di dalam dan di luar pengadilan 
dan dapat menunjuk kuasa hukum untuk mewakilinya sesuai dengan peraturan perundang-undangan. Melaksanakan wewenang lain sesuai dengan peraturan perundang- undangan.

Menurut (Moenir, 2000) dalam pelayanan terhadap beberapa faktor pendukung yang penting, antara lain: Faktor kesadaran, Faktor Sarana dan Prasaran, Faktor Pendapatan, Kesadaran masyarakat, Sumber daya aparatur

\section{METODE PENELITIAN}

Penelitian ini adalah menggunakan pendekatan deskriptif yaitu penelitian Kualitatif. Dalam penelitian yang mengenai Analisis Kepuasan Masyarakat Terhadap Kinerja Kepala Desa Medan Estate Kecamatan Percut Sei Tuan Kabupaten Deli Serdang, Metode Penelitian Kualitatif adalah prosedur penelitian yang menghasilkan data deskriptif berupa kata-kata tertulis atau lisan dari orang-orang dan perilaku yang diamati. Penelitian ini akan dilakukan dikantor Kepala Desa Medan estate, jalan kolam Kecamatan Percut Sei Tuan Kabupaten Deli Serdang, waktu penelitian dilaksanakan pada Bulan Oktober 2018 sampai dengan Bulan November 2018. Yang menjadi informan utama dalam penelitian ini adalah Pegawai Kantor Desa Medan Estate. Adapun informan kunci dalam penelitian adalah Kepala Desa Medan Estate, dan informan tambahan dalam penelitian ini adalah masyarakat Desa Medan Estate.

Fokus pelitian mengenai kinerja Kepala dalam memberikan pelayanan, sesuai dengan teori kinerja Dwiyanto (2005): 1. Produktivitas; 2. Kualitas layanan; 3. Responsivitas; 4. Akuntabilitas

Teknik Pengumpulan data yang digunakan adalah: Observasi, Wawancara, dan Dokumentasi. Teknik analisis data yaitu mereduksi data yang dirangkum memilih hal-hal pokok, memfokuskan pada hal-hal yang penting, dicari tema, polanya dan membuang yang tidak perlu. Penyajian data dengan menarasikan hasil data yang diperoleh untuk melihat hubungan antar kategori dan sejenisnya kemudian menarik kesimpulan sesuai dengan data yang diperoleh.

Informasikan secara ringkas mengenai materi dan metode yang digunakan dalam penelitian, meliputi subjek/bahan yang diteliti, alat yang digunakan, rancangan percobaan atau desain yang digunakan, teknik pengambilan sampel, variabel yang akan diukur, teknik pengambilan data, analisis dan model statistik yang digunakan.

\section{HASIL DAN PEMBAHASAN}

Dalam hal produktivitas pelayanan, Dari hasil penilitian ini ditemukan bahwa Pemerintah Desa Medan Estate sudah memiliki kemampuan dalam menjalankan tugastugasnya.data yang diperoleh menunjukkan bahwa menjadi aparat Pemerintah Desa cukup menjadi jaminan untuk mampu bekerja optimal meningkatkan produktifitas yang tinggi serta meningkatkan profesionalisme dalam bekerja akan selalu terkait dengan ukuran-ukuran atau kinerja. Dalam bidang pemerintahan, tugas pelayanan mempunyai peranan sangat besar karena menyangkut kepentingan umum, bahkan menyangkut rakyat secara keseluruhan dalam hal ini pelayanan yang dimaksud adalah pelayanan administrasi dan surat keterangan. Kualitas Pelayanan yang dilakukan aparatur Pemerintah Desa Medan Estate dalam proses pelayanan administrasi kependudukan dalam melayani masyarakat. 
Dalam kerjasama antar perangkat desa, baik antara kepala desa dan perangkatnya maupun antara sesama perangkat dalam suatu organisasi pemerintah desa sangat diperlukan dalam mencapai tujuan organisasi, begitu pula dalam memberikan pelayanan kepada masyarakat. Aparat hendaknya bekerjasama dalam menyelesaikan tugas yang diermban. Setelah penulis melakukan pengamatan berlangsung di Desa Medan Estate, kerjasama antara sesame perangkat terjalin dengan biasa saja. Partisipasi Masyarakat sangat dibutuhkan untuk menunjang kinerja para aparat dalam pemberian pelayanan. Tanpa adanya partisipasi dari masyarakat, para aparat seakan bekerja dengan sia-sia. Partisipasi Masyarakat dibutuhkan untuk mentaati semua aturan-aturan yang berlaku.

Sebagai Perangkat Desa terdapat sebagai unsur aparatur desa dalam menjalankan suatu Pemerintah dituntut untuk melaksanakan fungsi dan tugasnya sebagai abdi negara dan abdi masyarakat. Namun kenyataan di lapangan berbicara lain dimana masih banyak ditemukan perangkat desa yang tidak menyadari akan tugas dan fungsinya tersebut sehingga seringkali timbul ketimpangan-ketimpangan dalam menjalankan tugasnya. Akuntabilitas pelyananan yang dapat dipertanggung jawabkan sesuai dengan ketentuan peraturan perundang-undangan. Sebagai pertimbangan moral dipergunakan untuk memenuhi pembenaran atas suatu arah tindakan. Akuntabilitas atau pertanggungjawaban etis ini akan menunjukkan sebeberapa besar tingkat kesesuaian penyelenggaraan kegiatan dalam implementasi kebijakan pemerintah dengan ukuran nilai-nilai atau norma eksternal yang ada dimasyarakat.

Pelayanan kinerja Kepala Desa terhadap masyarakat sangatlah puas dalam pengurusan surat dikantor Kepala Desa dan dapat melayani masyarakatnya dengan bagus, sehingga masyarakat pun terasa puas dalam pelayanan dikantor Kepala Desa. selalu berdisiplin dan tepat waktu untuk melayani masyarakat. Sehingga Kepala Desa memberikan yang terbaik buat bawahannya, Kepala Desa pun bekerja sama dalam Perangkat Desa serta Sekretaris Desa dan membentuk suatu struktur organisasi dalam setiap bidang. Perangkat desa pun tiap bulannya mengisi hasil laporan kinerjanya untuk Kepala Desa agar Kepala Desa dapat menilai Perangkat Desa dalam kinerjanya bagus atau tidak bagus dalam bekerja. Perangkat Desa melayani masyarakatnya yang bagus dan sopan, sehingga masyarakat yang dalam pengurusan surat terasa senang dan samasama puas. tidak ada sedikit pun masyarakatnya menjadi kecewa dalam pelayanan pengurusan dikantor Kepala Desa, terkadang masyarakat saja yang mempersulit dirinya sendiri dalam pengurusan surat dikantor Kepala Desa, kadang perangkat desa mempersulit masyarakatnya dalam pengurusan surat dan perangkat desa pun meminta uang kepada masyarakatnya untuk pengurusan surat agarcepat selesai. Kalau suka duka yang dialami dalam kinerja pegawai belum ada sama sekali terhadap masyarakat sehingga masyarakat merasa puas dalam mengurus surat di Kantor Kepala Desa.

Sekretaris Desa mempunyai tugas yang bertanggung jawab atas semua pekerjaanya walaupun kepala desa tidak dapat hadir bekerja, maka Sekretaris Desa yang bekerja dan membentuk suatu tim dalam bekerja sehingga perangkat Desa dapat melayani masyarakatnya sendiri. Kalau pengurusan surat diKantor Desa Medan Estate kami siap melayani masyarakat agar masyarakat tidak kecewa sama kami dan Perangkat Desa yang mengangani masyarakat dalam pengurusan surat misalnya membuat surat domilisih, KTP, surat pindah penduduk, surat kematian dan kartu keluarga, dalam pembuatan surat sudah ada masing-masing pada bagiannya sehingga Perangkat Desa pun siap melayaninya. Sebagai Kepala Desa Medan Estate, harus memperhatikan perangkatnya dan menegaskan agar tidak lalai bekerja dalam pengurusan surat, masyarakat pun tidak merasa kecewa terhadap pengurusan surat dikantor Desa. Perangkat Desa bertanggung jawab atas melayani masyarakat. 


\section{SIMPULAN}

Bentuk pelayanan yang diberikan pemerintahan desa Medan Estate meliputi pelayanan dalam urusan umum seperti pelayanan pembuatan surat-surat dan pelayanan lainnya sesuai dengan tugas masing-masing aparat desa. Kepala desa telah memberikan kewenangan kepada perangkat desanya untuk melaksanakan tugasnya sesuai dengan asas penyelenggaraan pelayanan yang baik sesuai dengan peraturan desa yang telah ditetapkan. Masyarakat mengharapkan dalam penyelenggaraan pelayanan publik antara lain semakin meningkatnya kualitas pelayanan publik dalam wujud pelayanan yang cepat, mudah, berkeadilan, berkepastian hukum, transparan, aman, tepat, dan dapat dipertanggungjawabkan. Kepala Desa sudah berusaha melaksanakan tugasnya sebagai kepala desa untuk membina perangkat desanya dan masyarakat desanya, namun kurang tegas dalam menangani perangkat yang sering membolos bekerja, perlu diperbaiki dalam konteks pembinaan perangkatnya agar pelaksanaan penyelenggaraan urusan pemerintahan benar-benar dilaksanakan sesuai dengan tugas dan wewenangnya dan dilaksanakan berdasarkan prinsip-prinsip pemerintahan yang baik.

\section{DAFTAR PUSTAKA}

Beratha, D. N. (2000). Desa Masyarakat Desa dan Pembangunan Desa. Jakarta: Ghalia Indonesia.

Cahyadi, B., dan Abdul K., (2015). Peranan Tata Usaha Bagian Umum Kantor Bupati Deli Serdang dalam Meningkatkan Pelayanan, JPPUMA: Jurnal Ilmu Pemerintahan dan Sosial Politik UMA (Journal of Governance and Political UMA), 1 (1): 14-24

Deliana, \& Irwan N., (2016). Kinerja Pegawai Dalam Memberikan Pelayanan Kesehatan di Puskesmas Medan Denai Kota Medan, Jurnal Administrasi Publik Universitas Medan Area, 4 (2): 152-161

Dwiyanto, A. (2005). Penilaian Kinerja Organisasi Publik. Yogyakarta: Jurusan Administrasi Negara.

Hendrawan, A.I. Kusmanto, H. \& Warjio. (2018). Pengaruh Kualitas Pelayanan terhadap Kepuasan Publik di Badan Pengelolaan Pajak dan Retribusi Daerah Kota Medan. Jurnal Administrasi Publik : Public Administration Journal. 8 (1): 65-84.

Lupiyoadi, \& Hamdani. (2006). Manajemen pemasaran Jasa Edisi 2. Jakarta: Salemba empat.

Moenir. (2000). Manajemen Pelayanan Publik. Jakarta: Bina Aksara.

Pasolong, H. (2007). Teori Administrasi Publik. Bandung: Alfabeta.

Sari, P., \& Bahrum J., (2016). Pengaruh Kualitas Pelayanan TerhadapKepuasan Anggota Perpustakaan Kota Medan, Jurnal Administrasi Publik Universitas Medan Area, 4 (1): 1-15

Sukamma, L.E., dan Abdul M., (2014). Pengaruh Kualitas Pelayanan Terhadap Kepuasan Nasabah PT. Pegadaian (Persero) Cabang Madala Medan, Jurnal Administrasi Publik Universitas Medan Area, 2 (1): $1-7$

Supranto. (1997). Pengukuran tingkat kepuasan pelanggan. Jakarta: Rineka Ipta.

Supratna, T. (2003). Administrasi Birokrasi dan pelayanan Publik. jakarta: Nimas Multima. 